\title{
PEMBUATAN PROTOTIPE APLIKASI DISTRIBUSI PANGAN BERBASIS SISTEM INFORMASI GEOGRAFIS (SIG)
}

\author{
Henny Medyawati $^{1}$, Budi Setiawan ${ }^{2}$, Ega Hegarini ${ }^{3}$, Imam Ahmad Trinugroho ${ }^{4}$ \\ Fakultas Ilmu Komputer dan Teknologi Informasi, Universitas Gunadarma, Indonesia \\ Email: ${ }^{1}$ henmedya@staff.gunadarma.ac.id, ${ }^{2}$ buset@staff.gunadarma.ac.id, \\ ${ }^{3}$ ega@staff.gunadarma.ac.id, ${ }^{4}$ imam@staff.gunadarma.ac.id
}

\begin{abstract}
Food distribution and supply chain are the main problems to achieve food security in Indonesia. Geographical gaps, poor transportation systems and social differences in Indonesia induce a high complexity challenges to implement a perfect distribution system that can suitable with Indonesia characteristic. The purpose of this research is building a prototype for food distribution application using geographical information system (GIS) that can be implemented in Indonesia. GIS can visualize the entire data layer into a map which is easier to analyze. Indonesia consists of 34 provinces that spread over many island, each has specific geographical profile and transportation problems. This can be used as data layers with other instruments which related with food distribution in Indonesia. Building a food distribution application prototype is part of developing food distribution system which produce prototype of the system. Prototyping approach is being used to evaluate the designing result of GIS with analyzing features for food distribution in Indonesia. Final result for this research is an application that can be implemented into food distribution system that can create a stable food security in Indonesia, for all of the provinces.
\end{abstract}

Keywords: GIS, food distribution, food security, food distribution application

\section{PENDAHULUAN}

Kebutuhan pangan merupakan kebutuhan dasar manusia yang sangat penting dan harus dipenuhi oleh pemerintah dan masyarakat secara bersama-sama. UU No. 7 Tahun 1996 mengamanatkan pemerintah sebagai pihak yang menyelenggarakan pengaturan, pembinaan, pengendalian dan pengawasan kebutuhan pangan, sementara masyarakat merupakan pihak yang menyelenggarakan proses produksi dan penyediaan, perdagangan, distribusi serta berperan sebagai konsumen. Dalam rangka memenuhi kebutuhan pangan dibutuhkan suatu sistem penyelenggaraan pangan yang dapat memberikan perlindungan bagi pihak yang mengkonsumsi maupun yang memproduksi pangan, sistem penyelenggaraan pangan yang baik harus dapat memenuhi kebutuhan dasar manusia yang memberikan manfaat secara adil, merata dan berkelanjutan dengan berdasarkan pada kedaulatan pangan, kemandirian pangan dan ketahan pangan (Syaifullah, 2008).

Menurut UU no. 18 Tahun 2012 tentang pangan, negara mempunyai kebebasan untuk menentukan kebijakan pangannya secara mandiri, tidak dapat didikte oleh pihak mana pun, dan para pelaku usaha pangan mempunyai kebebasan untuk menetapkan dan melaksanakan 276 
usahanya sesuai dengan sumber daya yang dimilikinya. Untuk memenuhi konsumsi pangan tersebut harus memperhatikan 3 hal pokok (Rusastra, Geoff Thompson, J. W Tacco Bottema, and Robert Baldwin, 2008), yaitu:

a) Ketersediaan pangan yang berbasis pada pemanfaatan sumber daya lokal secara optimal;

b) Keterjangkauan pangan dari aspek fisik dan ekonomi oleh seluruh masyarakat; serta

c) Pemanfaatan pangan atau konsumsi Pangan dan Gizi untuk hidup sehat, aktif, dan produktif.

Pewujudan ketersediaan pangan yang berbasis pada pemanfaatan sumber daya lokal secara optimal dilakukan dengan penganekaragaman pangan dan pengutamaan produksi pangan dalam negeri. Pewujudan keterjangkauan Pangan dari aspek fisik dan ekonomi dilakukan melalui pengelolaan stabilisasi pasokan dan harga pangan pokok, pengelolaan cadangan pangan pokok, dan pendistribusian pangan pokok. Dalam mewujudkan ketersediaan Pangan, berdasarkan UU no 18 tahun 2012 tentang Pangan, Pemerintah dan Pemerintah Daerah harus melaksanakan kebijakan Pemerintah di bidang distribusi, pemasaran, perdagangan, stabilisasi pasokan dan harga pangan pokok serta bantuan pangan (Hariyadi, 2014).

Distribusi pangan merupakan suatu proses yang diperlukan untuk menyalurkan produk komoditas pangan dari produsen agar dapat sampai ke konsumen tepat waktu dan jumlah yang cukup serta terjangkau oleh daya beli masyarakat. Berdasarkan UU No. 18 tahun 2012, distribusi pangan dilakukan untuk memenuhi pemerataan Ketersediaan Pangan ke seluruh wilayah Negara Kesatuan Republik Indonesia secara berkelanjutan. Distribusi Pangan dilakukan agar perseorangan dapat memperoleh Pangan dalam jumlah yang cukup, aman, bermutu, beragam, bergizi, dan terjangkau. Pemerintah dan pemerintah daerah bertanggung jawab terhadap distribusi Pangan sesuai dengan kewenangannya.

Pada UU tentang pangan tersebut diuraikan bahwa distribusi pangan dilakukan melalui: pengembangan sistem distribusi Pangan yang menjangkau seluruh wilayah Negara Kesatuan Republik Indonesia secara efektif dan efisien. Pengelolaan sistem distribusi Pangan yang dapat mempertahankan keamanan, mutu, gizi, dan tidak bertentangan dengan agama, keyakinan, dan budaya masyarakat juga dilakukan untuk perwujudan kelancaran dan keamanan distribusi Pangan. Proses penyampaian produk komoditas pangan dari tingkat produsen seringkali harus melalui rantai pelaku pelaku distribusi pangan untuk dapat sampai kepada konsumen pemakai 
akhir. Aspek distribusi dalam hal ini sangat berperan dalam rangka stabilitas harga pangan nasional.

Permasalahan distribusi pangan seringkali terjadi karena adanya perbedaan yang menimbulkan kesenjangan (gap) antara produksi dan konsumsi, antara demand dan supply, yang antara lain terdiri dari geographical gap, time gap serta communication dan information gap. Ketersediaan data dan informasi distribusi pangan yang valid, terupdate dan mudah diakses merupakan salah satu upaya untuk mengantisipasi permasalahan distribusi yang disebabkan adanya gap tersebut. Analisa terhadap data dapat dilaksanakan sebagai langkah antisipasi serta bahan pembuatan kebijakan terkait stabilisasi harga dan pasokan pangan. Namun demikian ketersediaan data yang yang valid, terupdate, akurat, terintegrasi dan konsisten dari masing masing wilayah mengenai distribusi pangan masih belum memadai, sehingga sangat sulit untuk mewujudkan distribusi pangan yang efektif dan efisien, demi terwujudnya pemerataan ketersediaan pangan di seluruh wilayah Negara Republik Indonesia. (Pusat Distribusi dan Cadangan Pangan Badan Ketahanan Pangan, 2015)

Pemanfaatan SIG untuk pemetaan distribusi pangan telah dilakukan oleh peneliti lain, yaitu Bosona, Ingrid Nordmark, Gebresenbet Girma dan David Ljungberg (2013). Tujuan utama dari penelitian ini adalah untuk mengevaluasi kinerja jaringan distribusi makanan terintegrasi (Integrated Food Distribution Network) di Swedia. Analisis lokasi dan rute dilakukan dengan menggunakan data dari 11 pabrikan, 149 pabrikan, dan satu pusat distribusi. SIG dalam penelitian ini digunakan untuk analisis situs (Bosona, Ingrid Nordmark, Gebresenbet Girma dan David Ljungberg, 2013). Pemanfaatan SIG juga telah dilakukan di Negara Kenya untuk menangani kondisi tanggap darurat makanan (food emergency). Studi ini dilakukan oleh Moturi, dan Benjamin Otieno (2013), yang menyajikan kerangka kerja untuk respon darurat pangan dan menunjukkan penggunaan SIG sebagai solusi untuk merencanakan dan mengelola keadaan darurat pangan. Ini sangat penting di negara-negara tertentu seperti Kenya, di mana tidak ada kerangka komunikasi terpadu untuk memfasilitasi pengelolaan kedaruratan pangan (Moturi, dan Benjamin Otieno, 2013).

Charlianto, Edi Purnomo Putra dan Mikha Mangudu (2015) melakukan perancangan database untuk mendukung prototipe data warehouse pada Pusat Distribusi dan Cadangan Pangan, Kementerian Pertanian sebagai media penyimpanan historical data yang sudah terintegrasi yang berasal dari beberapa sumber data. Data warehouse tersebut digunakan sebagai pendukung untuk membantu manajemen tingkat atas dalam mengambil sebuah keputusan yang tepat pada suatu instansi dengan bantuan antar muka berbentuk pivot table dan atau sebuah laporan yang fleksibel dimana dapat melihat laporan dari berbagai sudut pandang 278 
serta dapat melakukan drill down. Data Warehouse yang dihasilkan masih membutuhkan alat tambahan untuk menganalisa gap yang timbul dari permasalahan distribusi, yaitu alat yang dapat menganalisa geographical gap dimana distribusi pangan dapat dianalisa lebih valid dan akurat dengan menganalisa lapisan lapisan pada sistem informasi geografis. (Charlianto, Edi Purnomo Putra dan Mikha Mangudu, 2015)

Dari uraian di atas dapat dirumuskan bahwa untuk masalah distribusi pangan tersebut sangat membutuhkan sebuah sistem informasi geografis peta jaringan distribusi pangan yang dapat mengumpulkan data yang valid, terupdate, akurat, terintegrasi dan konsisten. Dimana data yang diperoleh berasal dari seluruh aktifitas distribusi pada setiap daerah yang berfungsi untuk membantu pemerintah dalam mengambil keputusan dan atau membuat sebuah kebijakan baru.

Optimalisasi pembangunan sistem informasi geografis peta jaringan distribusi pangan dapat dilaksanakan melalui pengumpulan data yang dilaksanakan secara berjenjang di tingkat pusat dan daerah. Selain itu penyajian data distribusi pangan tersebut dalam bentuk peta jaringan distribusi pangan sangat membantu dalam analisa sistem yang lebih efektif, ini dikarenakan kondisi lokasi wilayah Indonesia yang sangat luas dan mempunyai faktor kendala yang bervariasi. Dengan analisa peta jaringan distribusi pangan, informasi lokasi, jarak antar lokasi, kondisi geografi dapat lebih mudah diidentifikasi. Sehingga untuk mendapatkan hasil analisa yang lebih lengkap, valid dan terintegrasi, Sistem Informasi Geografis (SIG) adalah solusi yang sangat tepat untuk masalah yang sudah diuraikan di atas.

Komoditas Pangan yang akan dianalisis diambil dari Renstra Badan Ketahanan Pangan Tahun 2015-2019, yaitu: Beras, Cabai Merah dan Bawang Merah. Secara umum tujuan penelitian ini adalah mengembangkan Sistem Informasi Geografis (SIG) untuk analisis distribusi pangan, sehingga tersedia basis data dan aplikasi distribusi pangan yang dapat digunakan untuk menganalisis, mengelola dan menyajikan data dalam bentuk Peta Jaringan Distribusi Pangan. Penelitian ini penting untuk dilakukan dalam rangka mendukung capaian Rencana Strategis Penelitian Perguruan Tinggi khususnya dalam bidang unggulan teknologi informasi dan komunikasi.

\section{BAHAN DAN METODE PENELITIAN}

\section{Sistem Informasi Geografis (SIG)}

Sistem Informasi Geografis (SIG) atau Geographical Information System (GIS) adalah sebuah alat bantu manajemen berupa informasi berbantuan komputer yang berkait erat dengan sistem pemetaan dan analisis terhadap segala sesuatu serta peristiwa yang terjadi di muka 
bumi. Teknologi SIG mengintegrasikan operasi pengolahan data berbasis database yang biasa digunakan saat ini, seperti pengambilan data berdasarkan kebutuhan serta analisis statistik dengan menggunakan visualisasi yang khas serta berbagai keuntungan yang mampu ditawarkan melalui analisis geografis melalui gambar-gambar petanya. (Prahasta, 2014)

Dari definisi yang ada, dapat diambil satu definisi yang dapat mewakili SIG secara umum, yaitu sistem informasi yang digunakan untuk memasukan, menyimpan, memanggil kembali, mengolah, menganalisa dan menghasilkan data bereferensi geografis atau data geospasial untuk mendukung pengambilan keputusan dalam perencanaan dan pengolahan seperti penggunaan lahan, sumber daya alam, lingkungan transportasi, perencanaan kota, pelayanan umum dan penentuan lokasi. SIG adalah sistem komputer, data geospasial dan pengguna, seperti gambar dibawah ini.

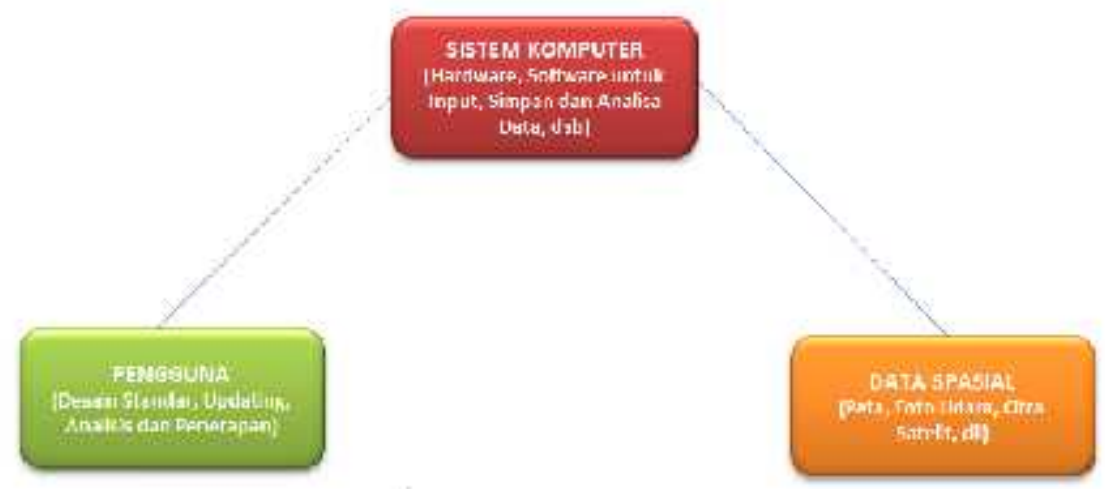

Gambar 1. Komponen Kunci SIG (Prahasta, 2014)

Data yang diolah pada SIG ada 2 macam yaitu data geospasial (data spasial dan data non-spasial). Data spasial adalah data yang berhubungan dengan kondisi geografi misalnya sungai, wilayah administrasi, gedung, jalan raya dan sebagainya. Seperti yang telah dijelaskan pada gambar diatas, data spasial didapatkan dari peta, foto udara, citra satelit, data statistik dan lain-lain. Hingga saat ini secara umum persepsi manusia mengenai bentuk representasi entity spasial adalah konsep raster dan vektor. Sedangkan data nonspasial adalah selain data spasial yaitu data yang berupa teks atau angka, biasanya disebut dengan atribut.

Data non-spasial ini akan menerangkan data spasial atau sebagai dasar untuk menggambarkan data spasial. Dari data non-spasial ini nantinya dapat dibentuk data spasial. Misalnya jika ingin menggambarkan peta penyebaran penduduk maka diperlukan data jumlah penduduk dari masing-masing daerah (data non-spasial), dari data tersebut nantinya kita dapat menggambarkan pola penyebaran penduduk untuk masing-masing daerah. 


\section{Konsep Model Data Spasial pada SIG}

Data spasial merupakan data yang paling penting dalam SIG. Data spasial ada 2 macam yaitu data raster dan data vektor :

\section{- Data Raster}

Model data raster menampilkan, menempatkan dan menyimpan spasial dengan menggunakan struktur matriks atau pixel-pixel yang membentuk grid. Akurasi model data ini sangat bergantung pada resolusi atau ukuran pixel-nya (sel grid) di permukaan bumi. Contoh data raster, dapat dilihat pada gambar dibawah, adalah citra satelit misalnya Spot, Landsat, dll. Konsep model data ini adalah dengan memberikan nilai yang berbeda untuk tiap-tiap pixel atau grid dari kondisi yang berbeda.

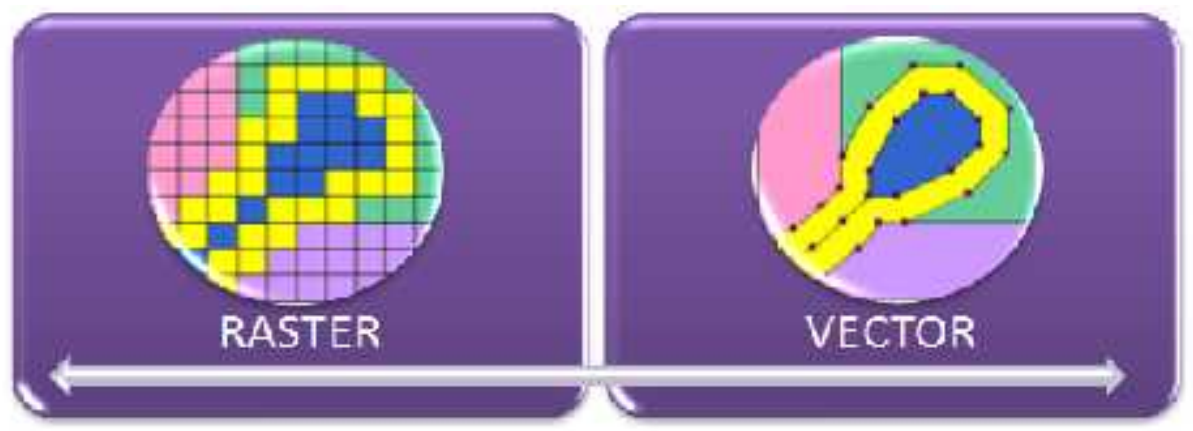

Gambar 2. Perbedaan Data Raster dan Vector (Prahasta, 2014)

\section{-Data Vektor}

Model data vektor yang menampilkan, menempatkan dan menyimpan data spasial dengan menggunakan titik-titik, garis-garis, atau kurva atau poligon beserta atributatributnya. Bentuk dasar representasi data spasial di dalam sistem model data vektor, didefinisikan oleh sistem koordinat kartesian dua dimensi (x,y). Gambar di atas adalah salah satu contoh konsep data spasial dihubungkan pula dengan atributnya.

\section{Peta Tematik}

SIG Distribusi Pangan juga memiliki Peta tematik (juga disebut sebagai peta statistik atau peta tujuan khusus), peta ini menyajikan patron penggunaan ruangan pada tempat tertentu sesuai dengan tema tertentu. Peta-peta tematik lebih menekankan variasi penggunaan ruangan daripada sebuah jumlah atau lebih dari distribusi geografis. Distribusi ini bisa saja merupakan fenomena fisik seperti iklim atau ciri-ciri khas manusia seperti kepadatan penduduk atau permasalahan kesehatan.

Peta Tematik adalah peta yang memperlihatkan data, baik secara kuantitatif maupun kualitatif dari unsur-unsur yang spesifik. Unsur-unsur tersebut ada kaitannya dengan detail 
topografi. Pada peta tematik, keterangan yang disajikan dalam gambar memakai pernyataan dan simbol-simbol yang memiliki tema-tema tertentu atau kumpulan tema-tema yang ada kaitannya antara satu dengan lainnya. Tema tersebut disajikan dalam bentuk yang berhubungan dengan unsur asli muka bumi atau unsur-unsur buatan manusia. Kadangkala bila diperlukan, peta tematik juga memperlihatkan situasi atau keadaan yang sebenarnya. (Indarto, 2010)

\section{Metodologi}

Metodologi merupakan cara atau teknis yang akan dilakukan dalam penyusunan grand design sesuai dengan kegiatan yang akan dilakukan. Dengan demikian metode pelaksanaan ini melekat pada masing-masing kegiatan yang direncanakan dalam mengupayakan pembangunan Sistem Informasi Geografis untuk Analisa Distribusi Pangan.

Pendekatan dari metodologi yang digunakan dalam pekerjaan pembangunan Sistem Informasi Geografis untuk Analisa Distribusi Pangan ini adalah pendekatan SDLC (System Development Life Cycle) dengan Prototyping Model. SDLC ini terdiri atas perencanaan (Planning), analisis (Analysis), desain (Design), implementasi (Implementation), dan pengujian sistem menggunakan sistem prototipe (System Prototype).

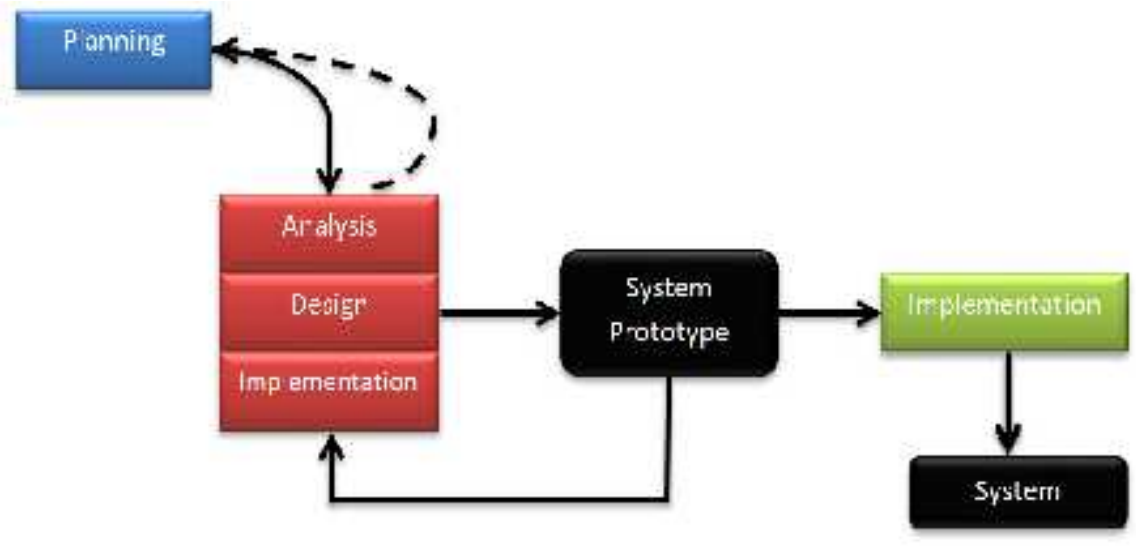

Gambar 3. Diagram SDLC

\section{Metode Pengumpulan Data}

Metode atau cara mendapatkan data sangat menentukan keakuratan data yang dihasilkan. Hal ini berguna untuk mencegah ketimpangan antara kondisi yang terjadi di lapangan dengan produk rencana yang dihasilkan. Dalam menentukan cara pengumpulan data sangat bergantung pada data yang dibutuhkan.

a. Kegiatan Pengumpulan Data. 
Berdasarkan jenis datanya maka kegiatan pengumpulan data melalui survei dilakukan melalui Survei Data Instansional, yaitu kegiatan survei yang ditujukan untuk mendapatkan data sekunder. Kegiatan survei ini dilakukan pada beberapa instansi/lembaga melalui permohonan data tertulis.

b. Kebutuhan Data.

Data sekunder yang dikumpulkan adalah data dalam bentuk dokumen kebijakan serta data-data tertulis lainnya. Sumber data yang digunakan dalam pemilihan indikator dan variabel dalam pembangunan Sistem Informasi Geografis Untuk Analisa Distribusi Pangan ini adalah:

- Database Spasial (Peta) yang terupdate.

- Database Atribut yang didapat dari instansi terkait seperti Departemen Pertanian dan Badan Pusat Statistik (BPS).

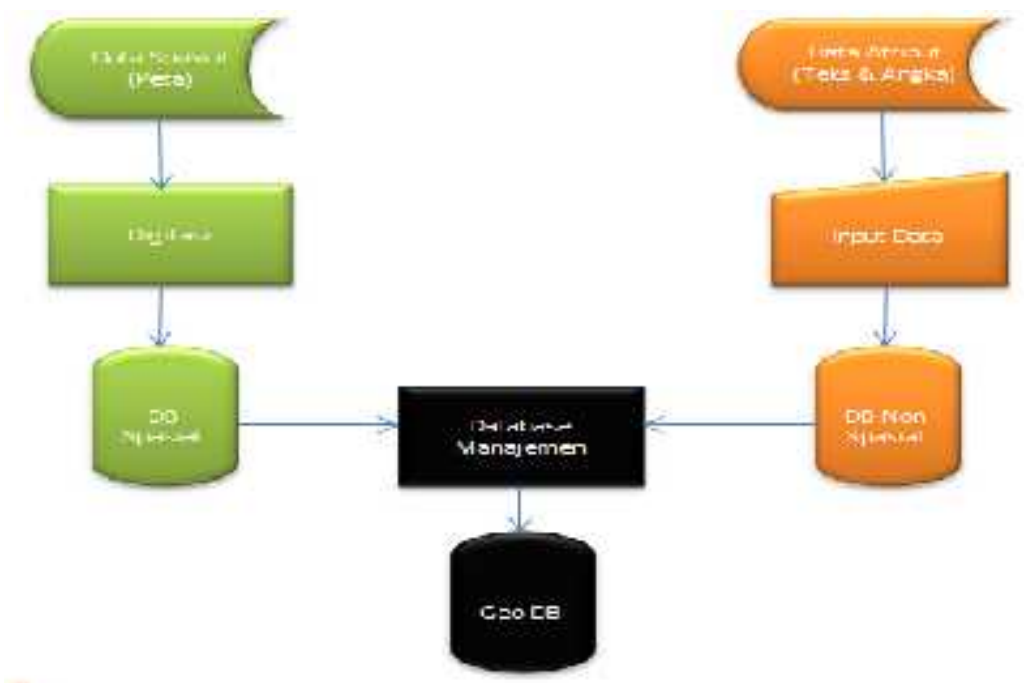

Gambar 4. Geo Database

c. Kegiatan Pengolahan dan Analisis Data.

Data merupakan kumpulan dari nilai-nilai yang mencerminkan karakteristik dari obyek dari suatu populasi. Data bisa berupa angka, huruf, suara maupun gambar. Dari data ini diharapkan akan diperoleh informasi sebesar-besarnya tentang populasi. Dengan demikian, diperlukan pengetahuan dan penguasaan metode analisis sebagai upaya untuk mengeluarkan informasi yang terkandung dalam data yang dimiliki. Statistika, sebagai cabang ilmu yang memberikan berbagai macam teknik dan metode analisis, telah menyediakan berbagai metode yang memiliki kegunaan yang berbeda-beda. Pengetahuan tentang kegunaan dari berbagai teknik ini perlu dimiliki untuk menghindari penggunaan yang tidak tepat. 
Secara umum, seperti halnya kegiatan-kegiatan yang lain, harus terdapat persiapan untuk berlanjut ke tahap berikutnya. Setiap metode analisis harus diawali dengan tahapan persiapan data. Tahapan persiapan data ini dilakukan dengan tujuan:

- Mengetahui karakteristik umum dari data yang dimiliki, misalnya peubah apa saja yang dimiliki, tipe-tipe data dari setiap peubah dan sebagainya. Pengetahuan ini dibutuhkan untuk menentukan metode apa yang nanti bisa digunakan.

- Menyaring data yang akan digunakan dalam analisis. Sebelum dilakukan analisis lebih jauh, kita harus bisa menyaring data yang ada. Mungkin saja tidak semua data yang digunakan, tapi hanya sebagian.

- Memperbaiki kesalahan-kesalahan yang ada pada data. Bukan hal yang jarang terjadi jika terdapat kesalahan pada data yang ada. Sehingga pada tahapan persiapan data, harus dipastikan kesalahan-kesalahan seperti ini tidak terjadi.

Dalam setiap tahapan analisis data akan senantiasa diuji silang dengan tahap lainnya. Pengujian silang itu dimaksudkan untuk mempertahankan kelengkapan dan konsistensi data. Sedangkan untuk kepentingan obyektivitas data akan dilakukan tringulasi antar sumber data. Semua data yang diperoleh akan dipaparkan apa adanya. Kemudian dilakukan kategorisasi berdasarkan model validasi yang telah dikembangkan dan selanjutnya dilakukan reproduksi untuk menemukan pola pendekatan ideal dalam pengembangan program.

Persiapan dan data analisis, yang antara lain menyangkut:

- Persiapan Data, yang mencakup langkah-langkah utama yang harus dilakukan, antara lain persiapan prasarana dan sarana untuk pengolahan data, entri data dan editing data, menghitung sampling weight, cleaning data dan membuat file, mengarsipkan data serta mengerjakan tabulasi.

- Analisis Data, yang meliputi pengertian kategorisasi data, pendekatan analisis desktiptif dan multivariat serta perhitungan berbagai statistik.

\section{Metode Pembahasan}

Pada pembahasan ini dirumuskan hal-hal yang terkait dengan pembangunan Sistem Informasi Geografis Peta Jaringan Distribusi Pangan Berbasis Web yaitu kebijakan yang telah ada terkait dengan distribusi pangan Dari pembahasan-pembahasan tersebut diharapkan 
diperoleh hasil akhirnya adalah Grand Design Sistem Informasi Geografis Untuk Analisa Distribusi Pangan.

\section{HASIL DAN PEMBAHASAN}

Tahapan dari Pembuatan prototipe aplikasi distribusi pangan berbasis SIG menggunakan metodologi SDLC (System Development Life Cycle). Tahapan utama SDLC adalah perencanaan, analisa, perancangan dan implementasi, dengan uraian sebagai berikut:

\section{Perencanaan}

Tahapan perencanaan pembuatan prototipe aplikasi distribusi pangan berbasis SIG dilakukan untuk merumuskan tujuan jangka pendek dan jangka panjang dari kegiatan pembuatan prototipe aplikasi distribusi pangan berbasis SIG. Selain itu dilakukan identifikasi kebutuhan dari kegiatan ini sehingga semua tahapan dapat berjalan dengan baik. Rincian dari tahapan perencanaan adalah sebagai berikut:

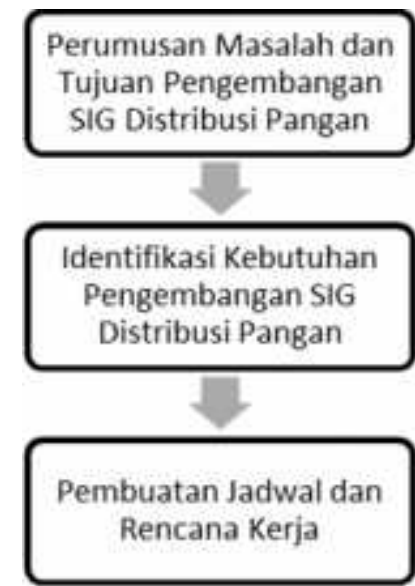

\section{Gambar 5. Tahapan Perencanaan}

\section{Analisa}

Setelah merumuskan masalah, melakukan identifikasi kebutuhan dan pembuatan jadwal serta rencana kerja, maka tahapan berikutnya adalah Analisa. Pada tahapan ini yang dilakukan adalah: 


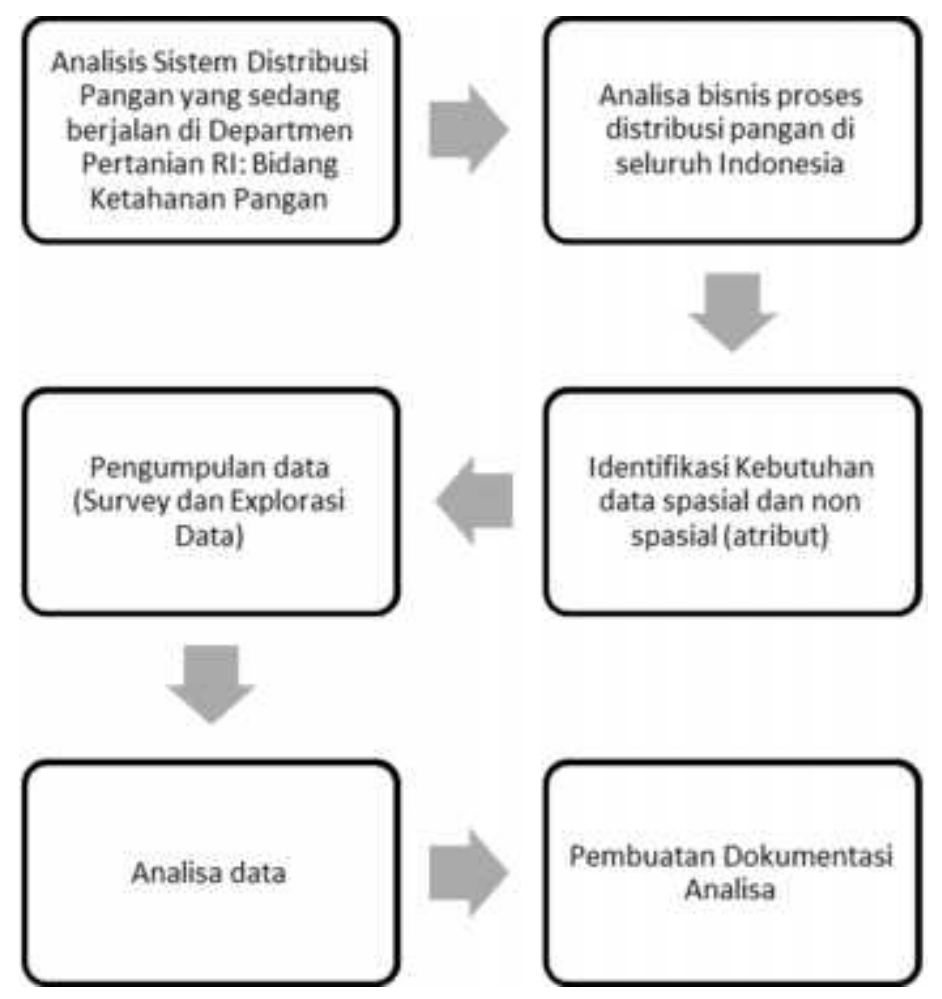

Gambar 6. Tahapan Analisa

Metode atau cara mendapatkan data sangat menentukan keakuratan data yang dihasilkan. Hal ini berguna untuk mencegah ketimpangan antara kondisi yang terjadi di lapangan dengan produk rencana yang dihasilkan. Dalam menentukan cara pengumpulan data sangat bergantung pada data yang dibutuhkan.

- Kegiatan Pengumpulan Data.

Berdasarkan jenis datanya maka kegiatan pengumpulan data melalui survei dilakukan melalui Survei Data Instansional, yaitu kegiatan survei yang ditujukan untuk mendapatkan data sekunder. Kegiatan survei ini dilakukan pada beberapa instansi/lembaga melalui permohonan data tertulis

- Kebutuhan Data.

Data sekunder yang dikumpulkan adalah data dalam bentuk dokumen kebijakan serta data-data tertulis lainnya. Sumber data yang digunakan dalam pemilihan indikator dan variabel dalam pembangunan Sistem Informasi Geografis Untuk Analisa Distribusi Pangan

Data yang dikumpulkan pada tahapan ini adalah data spasial yang berupa peta dasar Indonesia, peta provinsi di seluruh Indonesia serta koordinat titik ibu kota dari masing-masing provinsi. Sedangkan untuk data non-spasial berupa data distribusi pangan dari dan ke masing- 
masing provinsi, berikut dengan jumlah atau volumenya. Gambar peta dasar Indonesia serta provinsinya dapat dilihat di bawah ini:

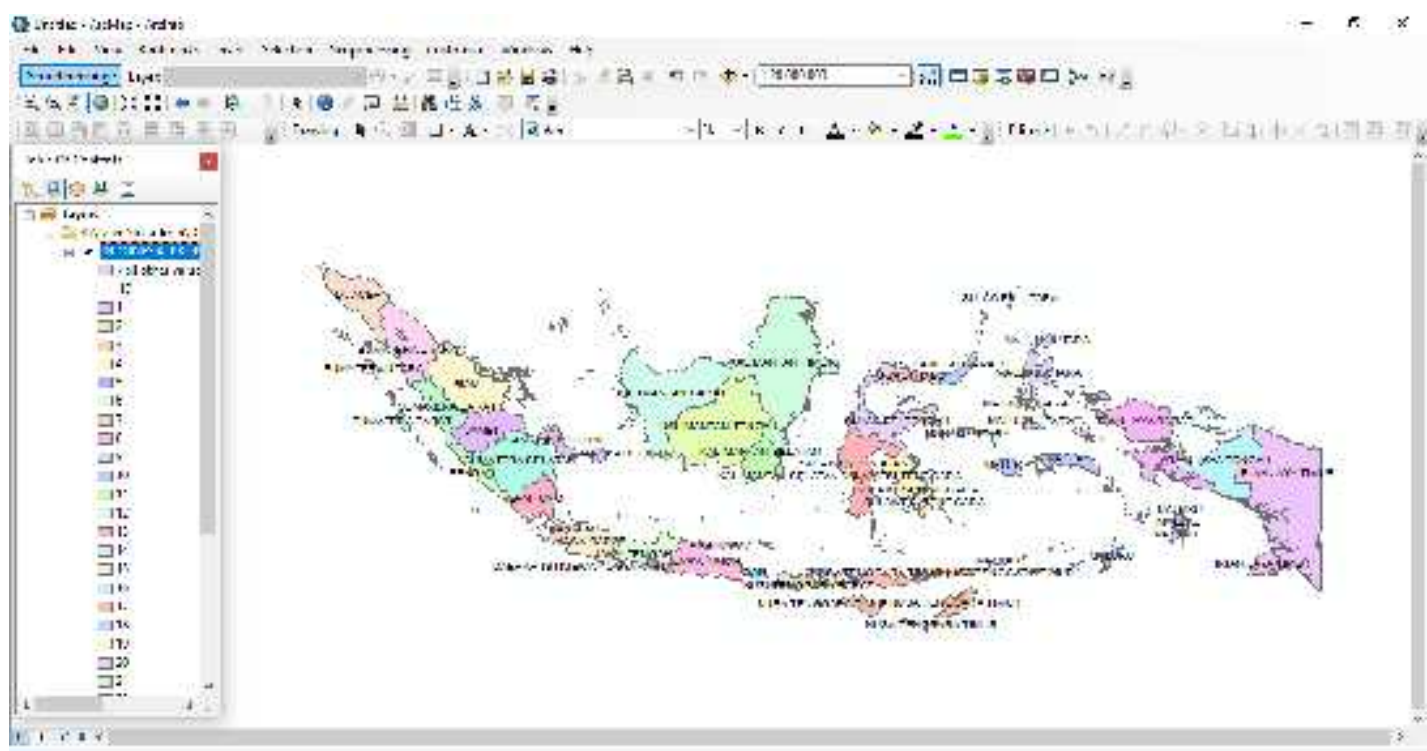

Gambar 7. Peta Indonesia dan Provinsinya

\section{Perancangan dan Pembuatan Prototipe Aplikasi Distribusi Pangan Berbasis SIG}

Pada tahapan ini dilakukan perancangan aplikasi distribusi pangan berbasis SIG berdasarkan dari hasil analisa yang dilakukan sebelumnya. Pada tahapan juga dilakukan pembuatan prototipe atau purwarupa dari aplikasi yang akan dijadikan model aplikasi distribusi pangan berbasis SIG. Purwarupa tersebut dibangun menggunakan Java dan JFlowMap. Tahapannya adalah:

1. Coding menggunakan Java

2. Input Peta yang sudah diolah di ArcMap10 di JFlowMap

3. Input data atribut dengan format CSV file

4. Kompile 
Tampilan awal purwarupa adalah sebagai berikut:

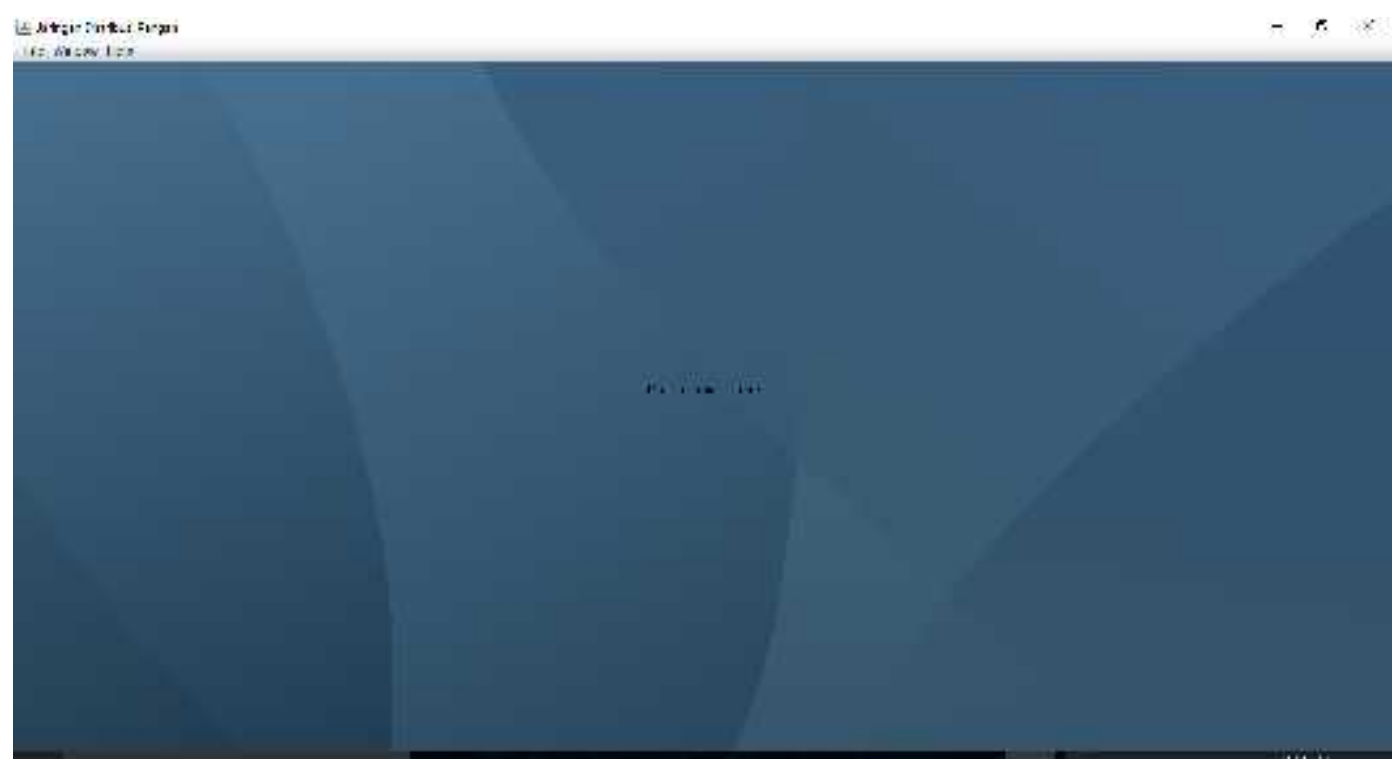

Gambar 8. Tampilan Awal Purwarupa SIG Distribusi Pangan

Lalu pilih file untuk menampilkan peta komoditas (beras, cabai merah atau bawang), jika memilih file beras maka akan tampil:

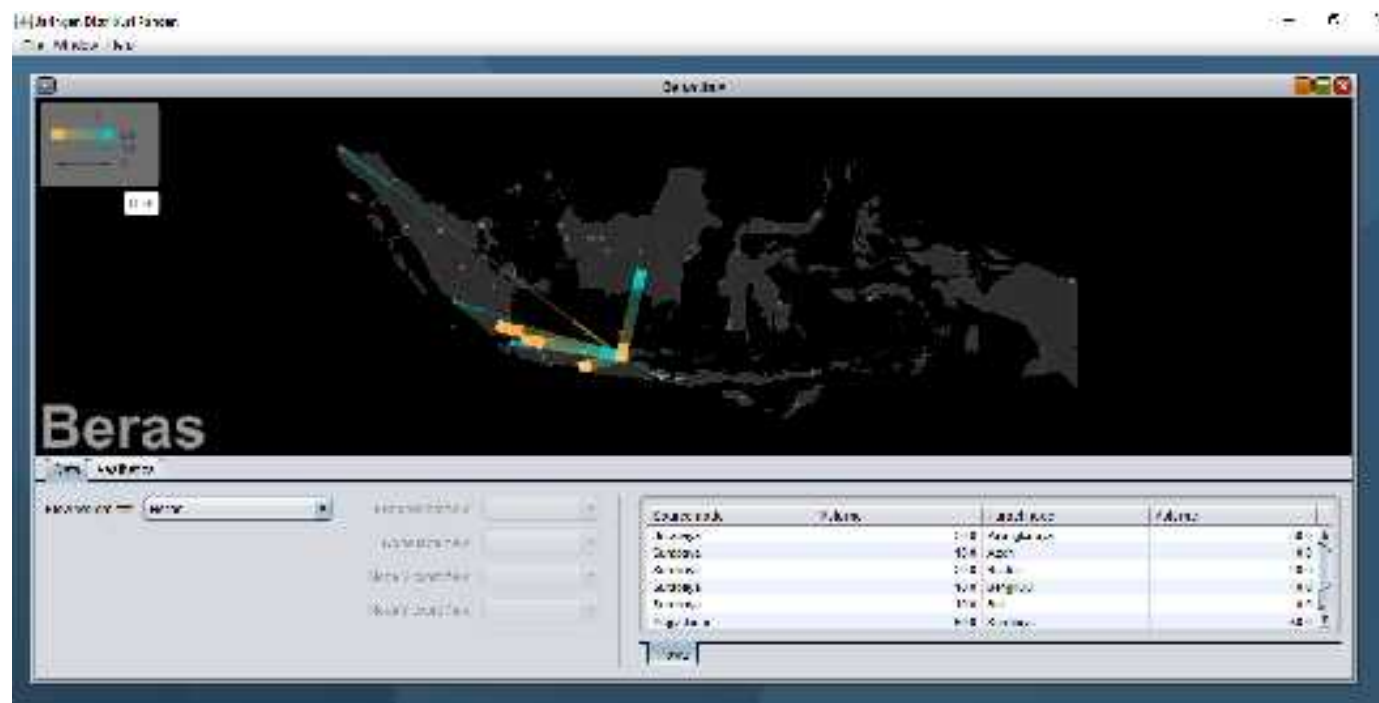

Gambar 9. Tampilan Peta Distribusi Beras

Tampilan di atas adalah peta distribusi beras di Indonesia, tampilan atas adalah peta, lalu panel bawah adalah datanya. Di panel bawah terdapat Aesthetics untuk merubah warna latar dan schemes dari aplikasi contohnya: 


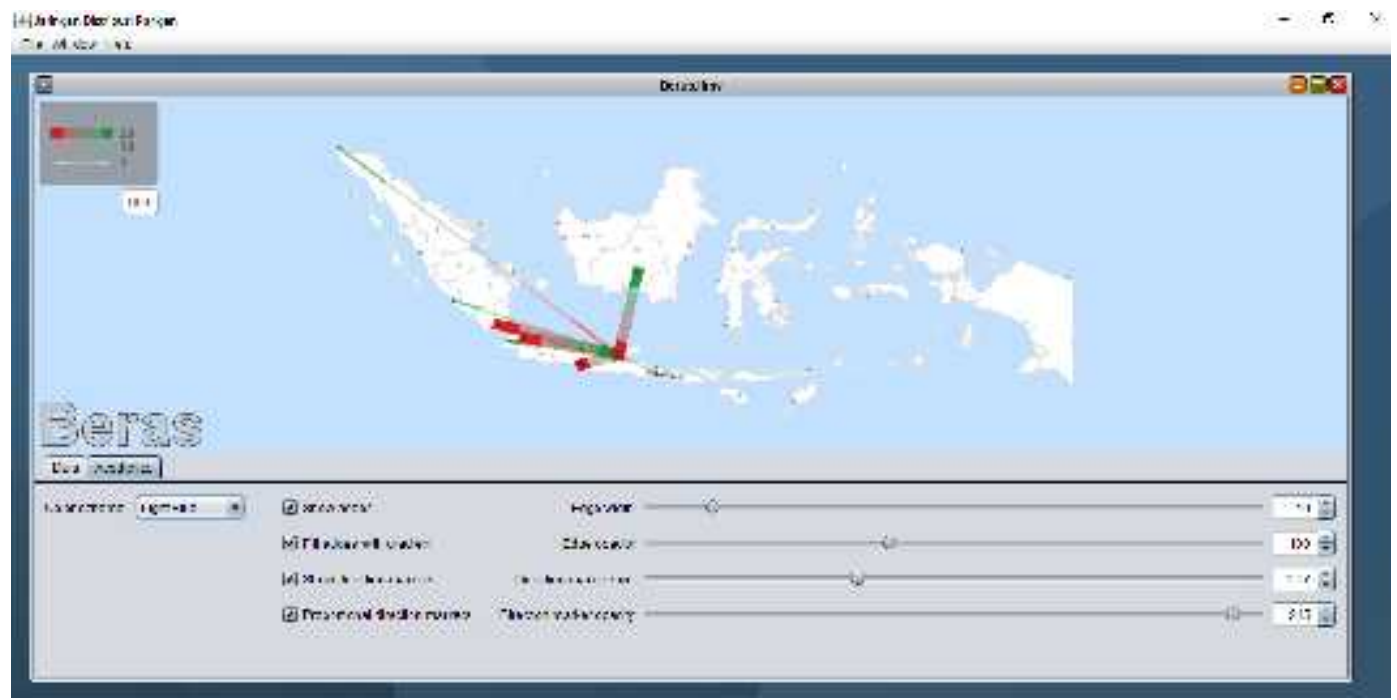

Gambar 10. Tampilan Peta Distribusi Beras dengan Color Scheme Light Blue

Pilihan Scheme adalah :

- Dark

- $\quad$ Light

- $\quad$ Black On White

- $\quad$ Light Blue

- Inverted

- Grey Red Green

Untuk menampilkan komoditas lain dapat dilakukan hal yang sama.

\section{KESIMPULAN}

Prototipe Aplikasi Distribusi Pangan berbasis SIG dikembangkan untuk mengatasi masalah distribusi pangan dengan banyak faktor yang mempengaruhi jalur distribusi dan cadangan pangan di masing masing wilayah. SIG memiliki beberapa layer peta tematik yang dapat dijadikan sebagai alat untuk menganalisa distribusi pangan. SIG Peta jaringan distribusi pangan sengaja dibangun berbasiskan web untuk dapat mempermudah pengguna dalam menggunakan SIG Peta Jaringan Distribusi Pangan ini, selain tidak membutuhkan keahlian khusus di bidang komputer, pengguna juga dapat melakukan analisa dengan lebih baik karena mudah menggunakannya.

Diharapkan Aplikasi ini menambah perbendaharaan dan alternatif metode dan teknik perencanaan distribusi pangan yang di Indonesia saat ini sangatlah kompleks, dimana dengan menggunakan Sistem Informasi Geografis diharapkan dapat menjadi solusi yang tepat dan efektif. Selain itu aplikasi dapat memberikan solusi dari hasil analisa distribusi pangan 
menggunakan sistem informasi geografis yang memadukan data spasial dan data atribut, sehingga masalah geographical gap tidak akan menjadi kendala.

\section{UCAPAN TERIMA KASIH}

Penelitian ini merupakan bagian dari hibah penelitian unggulan perguruan tinggi yang didanai oleh Kementerian Ristek Dikti. Terima kasih kepada Badan Ketahanan Pangan Kementerian Pertanian Indonesia untuk data dan informasinya.

\section{DAFTAR PUSTAKA}

Charlianto, Edi Purnomo Putra, Mikha Mangudu, Harisno, 2015. Perancangan Database Untuk Mendukung Prototype Data Warehouse Pada Pusat Distribusi Dan Cadangan Pangan, Kementerian Pertanian, ComTech Vol. 6 No. 3 September 2015

Hariyadi, Purwiyatno. (2014). INDUSTRI PANGAN: Menjawab Tantangan Ketahanan Pangan Mandiri dan Berdaulat. FOODREVIEW Indonesia. IX. 22-24.

Indarto. 2010. "Fundamentals of Geographic Information Systems". Jember, Jember University Press

Moturi, Christopher A. and Benjamin Otieno. 2013. "ICT and Food Security : Case of GIS in Food Emergency Response." International Journal of Applied Information Systems (IJAIS) Foundation of Computer Science FCS, Volume 6 - No. 1, September 2013, New York, USA, ISSN : 2249-0868

Prahasta, Eddy. 2014. Sistem Informasi Geografis Konsep-konsep Dasar (Perspektif Geodesi \& Geomatika). Informatika, Bandung

Pusat Distribusi dan Cadangan Pangan Badan Ketahanan Pangan, 2015, Panduan Analisis Jaringan Distribusi, Kementerian Pertanian Republik Indonesia

Rusastra, I Wayan, Thompson, Geoff, Bottema, J.W. Taco,Baldwin, Robert, Food security and poverty in the era of decentralization in Indonesia, CAPSA Working and Discussion Paper, 2008, p199

Syaifullah Yunan, 2008, Kebijakan Pangan Di Indonesia : Antara Swasembada Pangan dan Kecukupan Pangan, Jurnal Ilmiah Bestari Edisi No 38/XXI

Techane Bosona, Ingrid Nordmark, Girma Gebresenbet, David Ljungberg. 2013. "GIS-Based Analysis of Integrated Food Distribution Network in Local Food Supply Chain". International Journal of Business and Management; Vol. 8, No. 17

Yong-Wei Bao, Ming-Xuan Yu, Wei Wu, 2011, Design and Implementation of Database for a webGIS-based Rice Diseases and Pests System, 3rd International Conference on Environmental Science and Information Application Technology (ESIAT 2011), 2011, p536540 